\title{
6. Naturalism and the Plot in Creditors
}

Although Strindberg used the Preface to Miss Julie to proclaim that the Naturalist had abandoned guilt along with God ('skulden har naturalisten utstrukit med Gud' [SV 27, 106]), all the major texts that he wrote in the wake of The Son of a Servant in 1886 present the problem of guilt, of a just apportioning of blame for the way in which the events of the plot have unfolded, as an insistent one. 'Vems är felet?', 'Vem bär skulden?', 'Vems är skulden till vad som skett?' ask the heroes and the heroine of The Father, A Madman's Defence and Miss Julie in turn: Whose fault is it? Who is to blame? Whose is the guilt for what has happened? And notwithstanding his attempt to approach and explain 'the harsh, cynical, heartless drama that life affords' [SV 27, 102] with a notional scientific objectivity, that is, to analyse human behaviour from the point of view of a vivisector for whom the stage has been transposed into an operating theatre for the dissection of human souls, at least one early reviewer, Edvard Brandes, perceived the way in which accounts are finally settled in Creditors (1888) as a serious lapse on Strindberg's part from the naturalist doctrine of the author's impassibilité. Moreover, Strindberg's pained response to Brandes' criticism of his putative protagonist, Gustaf, as a moralist and a preacher might well be interpreted as betraying his own unease over some of the contradictions in which his elaboration of the plot of Creditors in accordance with naturalist principles had embroiled him. ${ }^{1}$

The context of his predicament is, of course, the evident loss during the nineteenth century of what Peter Brooks has called the 'sacred masterplot that organizes and explains the world', and hence the proliferation in history, mythology, anthropology and evolutionary biology (to mention only a few of the possibilities that Strindberg himself explored) of other scenarios wherein 'the plotting of the individual or social or institutional life story takes on new urgency.' ${ }^{2}$ This was ostensibly the position from which Strindberg felt compelled to write the natural history of his own life in The Son of a Servant, the one narrative which, or so he maintained in the fictitious interview that he wrote for his autobiographical fiction in lieu of a preface, was the privileged, indeed the sole story that the naturalist writer was in a position to tell with authenticity and authority [SV 20,373]. Nevertheless, when he returned to 
depicting the destinies of fictional characters in the late 1880s, he was still confronted by the exigencies of translating the plot laid down for individuals by their heredity, environment and the historical moment of their lives into effective theatre even though this plot, as his investigation of his own life had importantly demonstrated, was at once too vast and multiple in its combination of personal minutiae and immemorial interlocking causation ever to admit a clear, univocal interpretation or representation. 'The stone is set in motion,' as Adolf observes, in Creditors, 'but it wasn't the last drop of water which started it off, nor the first one - it was all of them together' [SV 27, 228]. Thus he goes on to conclude, using both the textual and the mathematical patterns of imagery which pervade this play, that one can neither 'translate a varied life into a single figure' (ett ensiffrigt tal [SV 27, 249]) nor make it all add up neatly since, quite simply, when one analyses the data of individual experience, 'it doesn't add up to a round sum' [SV 27, 250].

This is hardly surprising. At the time Strindberg was experimenting with a world view in which man was regarded as continuous with nature and conceivably subject to impersonal laws. Moreover, as Miss Julie remarks, in a last attempt to find the key to what has taken place during her last Midsummer night, as a consequence of the multiple motives enumerated by Strindberg in the Preface to the play [SV 27, 103]:

Who is to blame for all this? My father, my mother, myself? But I have no self of my own. I haven't a thought I didn't get from my father, not an emotion I didn't get from my mother, and this last idea - that everyone's equal - I got that from him, my fiancé. [SV 27, 187]

In Strindberg's naturalistic plays, man's determinations now emerge as not wholly his own, although s/he reaches them, and what the individual does seems to be at once himself, and therefore his responsibility, and yet, at some very real but submerged level, not himself. Determined yet strangely free and responsible before the 'mångfald av motiv' (multiplicity of motives [SV 27, 104]), the individual dwells in the accident of his character forever.

Moreover, while he sometimes professed a modish indifference to the implications of the naturalist world view ('after all the downfall of one family is only another's good fortune, it takes its place, and this alternation of rising and falling is one of life's greatest pleasures' [SV 27, 102]), Strindberg was nevertheless evidently disturbed by the apparent absence of any trace of moral order if, as he explained in The Son of a Servant, 'one doesn't choose one's urges' [drifter, SV 21, 16], and one's 'path was inevitably determined by heredity, temperament, and place in society' [SV 21, 147]. Indeed, in the most extreme formulations of his naturalist period, when he sought to dissolve the notion of a fixed, substantial selfhood which acts with conscious purpose and intent, 
Strindberg had placed in doubt the very notion of a plotted life. Like his near contemporary, John Ruskin, who referred to man as '[this] drift of human dust, and current of interchanging particles. ${ }^{3}$ Strindberg, in the Preface to Miss Julie, depicted the individual as a 'split and vacillating' patchwork made up of 'various stages of culture, past and present, scraps from books and newspapers, bits and pieces of different people, [and] shreds from fine clothes that have become rags' [SV 27, 105], and portrays such a figure in the heroine of the accompanying play, where Julie describes 'life and people [as] a scum which drifts, drifts on across the water, until it sinks' [SV 27, 135].

Certainly, there would seem to be no place in the form of drama envisaged in the preface to Miss Julie, where nature holds no clues nor answers to human moral dilemmas, for a plot that incorporates any conventional patterns of crime and punishment, or suffering and justice. Nor, indeed, does it seem possible in closing the plot to fall back on any of what Joseph Conrad (in 1905) wryly termed 'the usual methods of solution by rewards and punishment, by crowned love, by fortune, by a broken leg or sudden death'. ${ }^{4}$ And yet, of course, this is precisely what Miss Julie and - more elegantly - Creditors appears to do. With something of the formal precision of French classical tragedy, and progressing in three continuous scenes by means of a neat and almost stylized exchange of conversational partners that permits each side of a more or less conventional dramatic triangle to be illuminated in turn (the play might thus be appropriately located somewhere between Racine's Andromache and Beckett's Play), the action of Creditors embodies the working out of the equation contained in the initial situation in such a way that when it ends, the 'wronged' husband, Gustaf, has settled his account with his former wife, Tekla, and the man for whom she left him, Adolf, and can thus depart, his debt collected with the same punctiliousness as he pays the hotel bill for which he now rings.

Notwithstanding the self-consciously ironic tone of the play, which suggests that any attempt of the kind which Tekla (like Edvard Brandes) makes near the close to translate its network of financial imagery to do with debit and credit back into outmoded concepts of guilt and punishment is a regression in search of the false consolation conferred by fictional meaning, this formal as well as thematic consonance is achieved because the semantics of payment and debt and those of guilt are the same in Swedish as they are in several other European languages. The dual sense of 'skuld' as both 'guilt' and 'debt' allows Strindberg to establish and exploit a link between morality and economy, or price and retaliation, as essential features of what (in the novel Gothic Rooms of 1904) he will later define as 'this confused account of out and in, debit and credit, which is called life' [SS 40, 78]. Moreover, the frequent play upon popular expressions to do with the settling of accounts, paying off old scores, and balancing accounts throughout the text of Creditors enables him to summon 
up (notably in Gustaf's eloquent evocation of the Fall of Man in relation to Tekla's original adultery with Adolf) the deeply engraved trace of an ancient masterplot which, though redundant in terms of the vivisector's apprehension of the world, retains a capacity to animate and organize the text.

What one has here is, firstly, the adroit exploitation of those ghostly residues in language which linger on to provide the seemingly necessary armature of intelligibility in the text, rather like those spectres which Mrs Alving had shared with her audience a few years previously, in Ibsen's Ghosts. There is also the intimate psychological level where this dramatic triangle summons up, whether consciously or not, aspects of what in an unpublished note among his surviving papers Strindberg once referred to as the 'Affaire W-l' (SgNM 9:3, 21), that personal 'corpse in the cargo' [SV 27, 208] which recalls his relationship with Siri von Essen and her first husband, Car! Gustaf Wrangel, and which so often imprinted itself on the features even of his most evidently fictional texts, as here in Gustaf's name or the otherwise superfluous inclusion in the play of a child which was put away and died, on the grounds that it had begun to resemble Tekla's first husband, much like the one which Siri bore Strindberg less than a month after their marriage [SV 27, 208]. Similarly, the whole network of associations provoked by the vain attempt of Tekla and Adolf 'to play at brother and sister' [SV 27, 212] in the face of Gustaf's omniscient assumption of the patriarchal scriptor's role as the first corner, who fills Tekla's emptiness, or vacuity (tomrum), and inscribes his primary text upon her 'slate' [griffeltavla, SV 27, 261], ${ }^{6}$ evokes the imagery and circumlocutions of the correspondence with which Siri von Essen and Strindberg first seduced each other, and which Strindberg subsequently wished to see published as the epistolary novel He and She, as well as his first detailed treatment of the Woman Question in the play Sir Bengt's Wife (1882), which was also conceived as a vehicle to further Siri's theatrical career. And as in Miss Julie, where the coupling of Jean and Julie takes place in the shadow of the patriarchal Count, her father, the triangular relationship of Gustaf, Tekla and Adolf tellingly evokes the primal scene of Eden.

Ultimately, however, the power at large in Creditors to punish transgression comes from a preparedness the author shares with at least one of his characters to feel a guilt that has been internalized, irrespective of any of the arguments deployed to dismiss it in the course of the play. It erupts from within and, as Strindberg's later career amply demonstrates, it will brook no repression. Thus, in relation to Adolf and his former wife, Gustaf is also a kind of ghost, an embodiment of the past, and in her final speech Tekla acknowledges the fatal consequences of his return to haunt her, collect his dues and complete a plot in which his creator is also implicated: 'He who sees his own ghost [fylgia] dies' [SV 27, 272]. 
But more immediately crucial for the way in which the play is plotted than either of these aspects is the fact that behind the thematic relevance of the many allusions to finance and book-keeping, and hence to the ideas of order, morality and justice which they inescapably promote, there lies a complementary concern for aesthetic harmony, consonance, and poetic justice. For although the play may predicate a world without transcendence and hence one which lacks a guiding moral law, it requires its own internal coherence if it is to be dramatically effective. Even if life is identified as the formless 'scum' (sörja) of Miss Julie [SV 27, 135], an arbitrary concatenation of events devoid of any trace of those principles which might conceivably establish an order in human behaviour that works towards some comprehensible and just end, the naturalist writer is nevertheless compelled to embody the sense of such a world in a work that has artistic form, to have, if not a carefully fashioned beginning, middle and end, then at least an effective dénouement for that single scene ('la noix', the nut, as he called it in a letter of 29 November 1888 to Georg Brandes [VII, 184; 1, 291] $]^{7}$ which Strindberg currently believed was the substance of every worthwhile play. And hence, when Tekla finally raises the question of blame or guilt in human action in order perhaps partly to exonerate herself from any responsibility for the plot in which she is now caught up ('Christians say that it is Providence which governs our actions, others call it fate, aren't we innocent?' [SV 27, 269]), Gustaf's response, in the awkwardness of its attempt to reconcile the contradictions in which he, too, is trapped, might conceivably be seen as an expression of the dilemma of the naturalist writer, compelled to give form to human action and yet lacking the moral framework that would authorize the order which comes into existence along with the formal logic of the text: 'Up to a point, yes. But there's always a margin where guilt creeps in; and sooner or later our creditors present themselves! Innocent, but responsible! Innocent before Him, who no longer exists; responsible to oneself and one's fellow men' [SV 27, 269-70].

As the play proceeds, Gustaf also takes on an authorial role, not merely because, like Strindberg, he is determined to impose his text upon those around him and allot them parts in the drama of his life (in Strindberg's case this was then a matter of the role his wife should play both in and outside the theatre), but also because - as Edvard Brandes noticed - he seems to become the spokesman of the plot, almost the intrigue maker himself indeed, someone who stages his scene with Tekla in order to capture the attention of Adolf in the adjacent room before an audience that is as hypnotized by the events on stage as Adolf is, an audience, moreover, that is also, because of its voyeuristic role, made up of Gustaf's confederates.

What is more, Tekla also senses this. At one point she accuses Gustaf of creeping in with 'a vile plan to destroy my happiness' [SV 27, 266], something 
that he rather disingenuously denies. He did not plot what is taking place; things merely turned out as circumstances and the situation ordained. Having spotted Tekla on the steamer, he felt drawn to look in on her. Then 'your lamb [i.e. Adolf] threw himself straight into the arms of the wolf [SV 27, 266] and provoked him by recalling the book in which - like Strindberg in A Madman's Defence - she had given a public account of her first marriage, and branded him an idiot. Even so, when she returned, Gustaf claims not to have been following a preordained script: 'I didn't really know what I was going to say. Like a chess player, I had a number of possible plans, but which one I used depended on the moves you made. One thing led to another, chance played a part, and so I had you ditched' [i sumpen, SV 27, 267].

But once scripted chance can appear more theatrical or melodramatic than other aspects of the plot, as when, in Creditors, two female figures suddenly appear at the verandah door, apparently on cue, to catch Tekla in the embrace of Gustaf's compromising arms. The ultimate authority resides now not with the action but the author, who has written the event into his text: Gustaf is only his interpreter. Lacking a preordained script, it is the playwright who now selects events and dispenses justice. As his friend Birger Mörner once recalled Strindberg observing: 'Writing plays is nevertheless the most interesting of all. It means sitting like a little god and probing people's hearts and reins... judging them... punishing, acquitting or rewarding. ${ }^{8}$

On the one hand, therefore, the coherence and order which the play assumes as a work of art appears to readmit such order into the world it depicts: lives assume the contour of a plot, individuals gain destinies they may not themselves perceive, but which the audience is invited to unravel, and the actions of the characters produce not a random sequence of events but an interpreted series that concludes with a settling of accounts, a dramatic resolution which seemingly leaves no end untied. On the other hand, rather than being a regression to the artificial play-making of the pièce bien faite, as has sometimes been suggested, the degree of formal organization in Creditors already anticipates the patterning of Strindberg's post-Inferno drama, the repetitions and echoes of The Dance of Death, Crimes and Crimes, and To Damascus. In the series of dialogues between the different partners here, there is an element of play, and the three consecutive scenes amount to a kind of game like musical chairs, which affords both formal pleasure and a sense of life as theatre - as becomes apparent when Gustaf stage manages Adolf: 'I'll take up my post in there and watch while you play your scene in here. And when the performance is over, we'll change parts' [SV 27, 227]. Indeed, given the relatively small role played by the environment in fostering these characters' lives, it is the form rather than the set which creates the boundaries within which they are confined. And while the metatheatrical standpoint of A Dream Play is not 
yet explicit, there is in Strindberg's Naturalism, and particularly in its sense of character emplotted in action, an indication of the way in which people assume and exchange roles in the interplay of life which generally distinguishes it from Ibsen's dramas of contemporary life. In Strindberg, as Creditors goes some way to demonstrate, life is always theatre - and theatre, life. 